\title{
State \\ Dominance in Myanmar
}


The Institute of Southeast Asian Studies (ISEAS) was established as an autonomous organization in 1968. It is a regional research centre dedicated to the study of socio-political, security and economic trends and developments in Southeast Asia and its wider geostrategic and economic environment.

The Institute's research programmes are the Regional Economic Studies (RES, including ASEAN and APEC), Regional Strategic and Political Studies (RSPS), and Regional Social and Cultural Studies (RSCS).

ISEAS Publishing, an established academic press, has issued almost 2,000 books and journals. It is the largest scholarly publisher of research about Southeast Asia from within the region. ISEAS Publishing works with many other academic and trade publishers and distributors to disseminate important research and analyses from and about Southeast Asia to the rest of the world. 


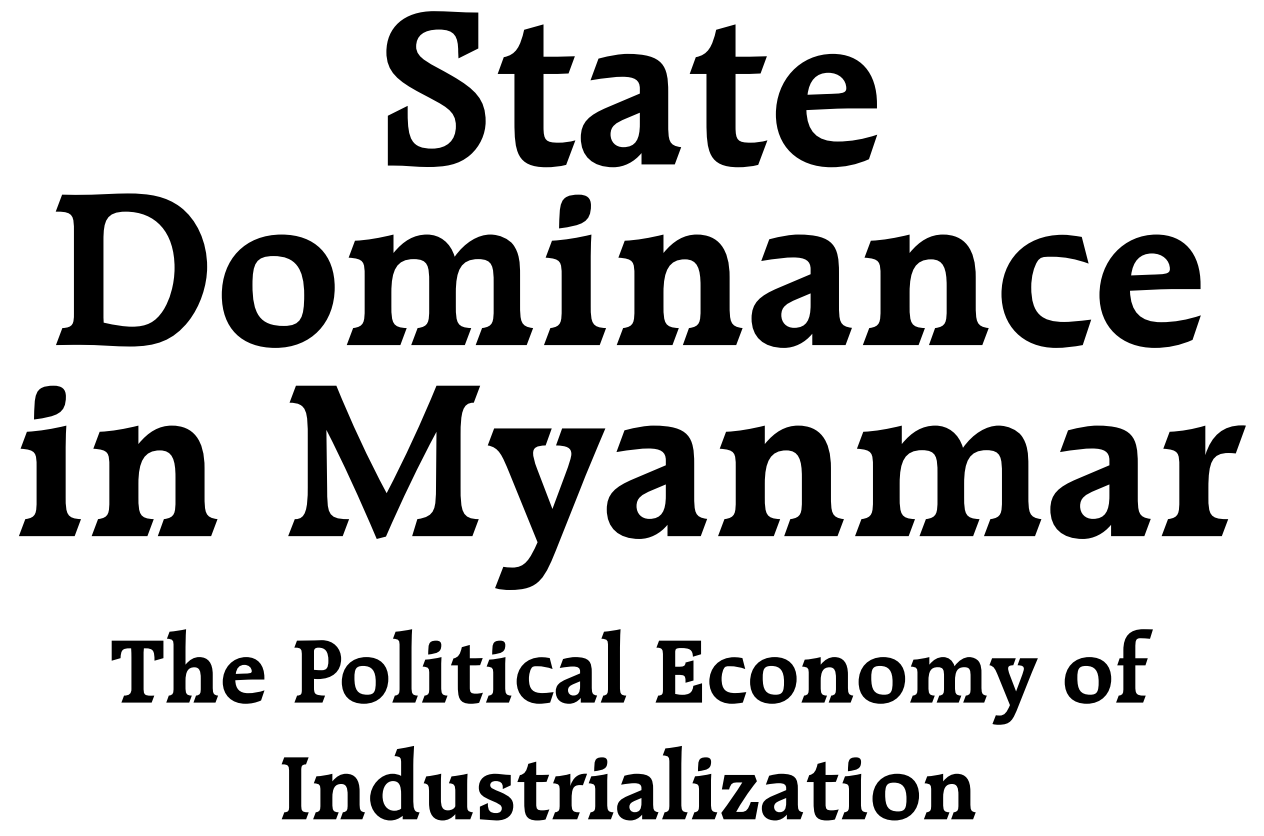

TIN Maung Maung Than

\section{누반ㄷ}

Institute of Southeast Asian Studies

Singapore 
First published in Singapore in 2007 by

ISEAS Publishing

Institute of Southeast Asian Studies

30 Heng Mui Keng Terrace

Pasir Panjang

Singapore 119614

E-mail: publish@iseas.edu.sg

Website: http://bookshop.iseas.edu.sg

All rights reserved. No part of this publication may be reproduced, stored in a retrieval system, or transmitted in any form or by any means, electronic, mechanical, photocopying, recording or otherwise, without the prior permission of the Institute of Southeast Asian Studies.

(C) 2007 Institute of Southeast Asian Studies, Singapore

The responsibility for facts and opinions in this publication rests exclusively with the author and his interpretations do not necessarily reflect the views or the policy of the publisher or its supporters.

\section{ISEAS Library Cataloguing-in-Publication Data}

TIN Maung Maung Than.

State dominance in Myanmar: the political economy of industrialization.

1. Industries-Burma.

2. Industrial policy-Burma.

3. Industrialization-Burma.

4. Burma-Economic policy.

I. Title

HD3616 B9T58

ISBN-13: 978-981-230-350-9

ISBN-10: 981-230-350-2

ISBN-13: 978-981-230-371-4

ISBN-10: 981-230-371-5

(soft cover-13 digit)

(soft cover-10 digit)

(hard cover-13 digit)

(hard cover-10 digit)

Typeset by International Typesetters Pte Ltd

Printed in Singapore by Kyodo Printing Co. (Singapore) Pte Ltd 